NORMA GIARRACCA \& TOMÁS PALMISANO ${ }^{1}$

\title{
Three food production logics: Are there alternatives to agribusiness? ${ }^{2}$
}

Departing from the global development of 'agribusiness', three distinct logics of production can be identified in the agricultural sector and in food production in particular: 1) peasant, 2) agribusiness, and 3) farmer or Chacarera (in Argentina). This last logic of production, in our hypothesis, maintains some interesting characteristics that have not yet completely disappeared but are at risk of disappearing in the medium term. This typology assumes different relations with the land, fundamental differences in production and labour processes, in production outlooks, and in the type of capital intervening, etc. Even if in our country ${ }^{4}$ for historical reasons the peasant form of production has not had a marked significance, it has recovered importance amidst the indigenous populations' processes of land recovery, together with the many criollos displaced from commercial agriculture that are also implementing this mode of production, encouraged by the guidelines from the international organization La Via Campesina.

\section{The peasant logic of production}

The peasant maintains a relationship of unity between family/work/land that enables a familial occupation, a valuation of the land as an instrument for work and a productive process with few capitalist components such as agroindustrial materials

\footnotetext{
1 Norma GiarRacca was Professor of Sociology in the University of Buenos Aires, Argentina. Tomas Palmisano is a researcher part of the Rural Studies group at the University of Buenos Aires.

2 This article was originally published in http://www.alternautas.net/blog/2020/12/4/three-foodproduction-logics-are-there-alternatives-to-agribusiness. This text is a translation by Ana Carballo of the original: Giarracca, N. y Palmisano, T. (2013). Tres lógicas de producción de alimentos: ¿Hay alternativas al agronegocio? En N. Giarracca y M. Teubal (coord.) Actividades extractivas en expansión: ¿ Reprimarización de la economía argentina.

3 In Spanish

4 Translator's note: Argentina
} 
and inputs or machinery. First, we must distinguish the peasant logic of production integrated to capitalist markets that prevailed in the decades of agrarian reforms or state interventions where food was produced for internal markets. This is the case of Mexico and many other countries with a peasant or campesina tradition during the period of import substitution industrialization (ISI). Later, some forms of production will emerge from other social movements towards the end of the twentieth century (the Landless Workers' Movement in Brazil is paradigmatic of this case) that will have a relative autonomy from capitalist markets. In the first case, authors, especially Armando Bartra (1979), proposed a differentiation of the peasant and capitalist forms of production that clarified various issues. First, that while in the capitalist mode of production labour is immediately subordinated to the capitalist process of valorisation (where the exploitation of workers is inherent), in the peasant mode of production, labour is only valorised through a series of mediations when it enters the circuit of capitalist markets. There, the authors demonstrate encounters between peasants and capital in a series of registers emerging mainly from historical processes of each country. Yet, the production market in an unequal exchange is the meeting point for the valorisation of peasant labour, which is added to other exploitation mechanisms inherent to labour markets (semi-proletarianization) or in the food or inputs markets.

This discussion is no longer a preoccupation for peasant studies in the twenty-first century. The valorisation of peasant labour is no longer seen as interesting because it is considered that both productive and commercial processes occur in spaces with relative autonomy from capitalist markets. And this happens both because neoliberal capitalism is not interested in peasant production as a source of food for local or national populations and because peasantries emerging from social movements towards the end of the twentieth and beginning of the twenty-first century have sought to create their own markets to stock and exchange their products. Agroecology is not only a mode of production of peasant movements (especially those organized within the Via Campesina) but also includes its own commercial networks. In a recent work (Vía Campesina, 2010), it is presented as a key concept that redirects towards an interdisciplinary approach to explain the functioning of agroecosystems. It implies principles to guide agricultural and productive practices to cultivate food and fibers without agrotoxins. Miguel Altieri, an important political ecologist cited in this work, states its main principles:

- To increase the recycling of biomass and achieve a balance in the soil 
nutrients;

- To ensure favorable soil conditions, with a high content of organic and biological matter;

- To minimize the nutrient loss of the system;

- To encourage the genetic diversification, as well as that of species, at a farm and landscape level;

- To increase the biological and synergistic interactions amongst the different agroecosystem components.

Finally, it is argued and to sum up,

that for the social movements within the Via Campesina, the concept of agroecology goes beyond ecological principles of production. To their agroecological vision, a series of social, cultural and political principles and goals is added. In this vision, for example, there cannot exist an 'agroecological latifundio' or 'agroecological plantation' that produces biofuels for cars instead of food and products for human beings. For us, then, agroecology is a fundamental pillar in the construction of food sovereignty and security' (Vía Campesina, 2010:16).

Yet, not all peasant communities use agroecology. It is a principle but it cannot be an imposition and this is clear in the diversity of modes of production that can be found in the regions articulated around the Via Campesina.

Agroecology is an ancestral practice within indigenous communities and of recent application in the criollo peasant communities. However, there are common characteristics amongst them that have persisted throughout time: a) The chief of production has under their control the decision of what and how to produce; b) even when recently more technological aids have been introduced, the locally produced 'techniques' prevail (or in many cases, those by the producers themselves); c) use value is more important than exchange value and; $d$ ) the agronomic practice is subjected to the function of preserving the land as an instrument for labour and to integrate the family to the peasant labour, independently of the agroecological use. ${ }^{5}$

\footnotetext{
${ }^{5}$ Land both for peasants as for indigenous people is conceived as a territory in the most full and diverse sense of the word: as a jurisdiction; as a geographic space; as a habitat or systemic group of resources essentual for the collective existence; as biodiversity and the ancestral knowledge connected to it; and as spaciality socially constructed linked to collective identity (Toledo Llancaqueo, 2005).
} 
Three food production logics | 100

\section{The agribusiness logic of production}

From the establishment of neoliberalism, a model of agriculture and livestock production has been expanding in Argentina, whose characteristics make it similar to other extractive dynamics in the country and around the world. Specifically, agribusiness is the rural expression of the neoliberal civilizing model. This implies a profound transformation of the productive structures and of the actors that work in and on them.

The Argentinian case is paradigmatic for the enormous expansion that this form of production has had and it is for this reason that we will refer particularly to its characteristics. Perhaps the first one to highlight is the requirement of production at a larger scale than in the past. From the 1970s there has been a recorded decrease in the number of Agricultural Holdings (AHs) in the country. While the 1969 National Agricultural Census recorded over half a million of AHs, this number had fallen to 333,533 in 2002 and the trend appears to have continued despite the lack of official reliable data. As it can be imagined, this process was accompanied by an increase in the average surface of land holdings across the country (a characteristic that will be detailed further below). Not only in the Pampas region, which will be the main stage for the expansion of the 'star' crop of this model, soybeans, but the scale of these units grew too in other regions. In these areas, crops that required high technological investments and much more spacious plantations than usual were introduced. Their establishment was favoured by policies of agricultural tax deferrals that increased in the $1990 s^{6}$ and introduced new products oriented to the external markets or to sectors of high purchasing power. In this manner, in regions where the average surface of the land holdings was around 5 hectares (ha), land holdings with surfaces over 25 ha. increased, with higher levels of investment both in the type of crops and in the technology applied (mainly in watering systems).

With this process of land concentration, there is also a strengthening of the understanding of land as a commodity whose symbolic value is entirely embedded in the business possibilities it offers. Both the patrimonial and territorial understanding

\footnotetext{
6 The agricultural deferments are a series of tax exemptions regulated by Law 22.021 sanctioned during the last dictatorship (1979) and extended during the nineties. This legislation provides businessmen that invest in agricultural holdings requesting high levels of capital payment assistance and exemptions to VAT, income tax, import duties, etc, Most of the entrepreneurial projects that were established correspond to productions oriented towards the external market or high purchasing power.
} 
of the land lose meaning in the face of a marketized notion of the land which, in a context characterized by the expansion of agribusiness activities, implies a constant pressure to displace other notions of territory (peasant, indigenous, farmer, etc.). This process has at least two clear dimensions. First, the economic dimension which has seen a constant increase of land prices, both for rent and for purchase. In practical terms this means more difficulties to access land for those with lower purchasing power and better possibilities for those with large businesses that can take advantage of the economies of scale and of strategies of hoarding of land for rent to sustain their privileged position. ${ }^{7}$ This process excludes many and increases the downward trend of number of works per hectare, principally those of family group that lose importance in relation to the salaried workers. This trend includes those connected directly to the production, the subcontractors ${ }^{8}$ or the outsourcing of workers through intermediary companies. That is, the contractual relations of salaried workers are erased and there is an accentuation of modes mediated by subcontractors and outsourcing of workers (See Aparicio, 2005).

The second dimension of this process is the escalation of rural violence. Physical injuries and even death are the result of territorial disputes unleashed by the logic of agribusiness. The expansion of the agricultural-pastoral land surface over the lands of peasant and indigenous communities has been enacted both through more silent displacement - in which the populations are displaced without much conflict either through scams or manipulation - and also through more violent forms, where public and private institutions react to families and organizations resisting displacement pushing forward a territorial reconfiguration that favours those with concentrated interests (GER 2004, GEPCyD 2010). At this point we should also highlight the violence over animals when moving from the old agricultural practices to the modern 'pig, poultry and beef factories'.

\footnotetext{
${ }^{7}$ For a detailed description of this process see Teubal and Palmisano (2013).

${ }^{8}$ In the literature, the concept of 'subcontractor' has a double meaning. On the one hand includes those that provide 'cultural' agricultural services (labelling, sowing, spraying, harvest, pruning, weeding, etc.) to different producers and on the other hand, to those who own machinery that also have their own lands (rented or owned) in production. In this case, we refer to the first meaning.
} 
Another important characteristic of the agribusiness logic is the expansion of strategies of vertical and horizontal integration from the biggest land holdings, encouraged by the incorporation of new technologies - in many cases patented - by transnational companies. The role of foreign capital increased particularly in two sectors. On the one hand, the provision of inputs (seeds, fertilizers, pesticides, etc.) became a key area where companies entered the market along with the expansion of the agribusiness logic which offered the technological breakthroughs of the 'transgenic revolution'. ' On the other hand, many local companies started processes of internationalization, particularly visible in the second sector that we will analyse: food processing and commercialization. Here, the majority of the local companies received foreign investment that restructured their share capital, at the same time as market concentration increased both in food production and commercialization, locally and internationally (Teubal and Rodriguez, 2002). In the case of agricultural products, foreign direct investment was more limited and in the majority of cases it was connected to mergers and shares traded in different stock exchanges.

Even if some of the agricultural activities that characterize agro-industrial models (Giarraca and Teubal, 2008) maintain their productive forms even if in a smaller, more concentrated market; in parallel specific strategies are developed to incorporate them into the agribusiness logic. Perhaps the clearest example is the sugar cane production industry, in which many sugar mills were acquired by transnational companies connected to agrofuels. In this case, the biggest 'technological jump' is in the higher echelons of the food chain production, adding a new step. In this way, the necessary investments to distil biofuels are added to those connected to land acquisition processes and the renewal of machinery (Mariotti 2011) ${ }^{10}$.

Added to these material technologies, there is a continued emphasis on the integration of different stakeholder networks into the agricultural food production chain. At first glance, these proposals appear to offer a mechanism of democratization within the agribusiness logic of production. Yet, this network-focused scheme hides the hierarchical nature of the socio-economic contexts in which large companies operate. The apparent equality of the reticular model proposed by think tanks may be thought of as a clear manifestation of the 'monoculture of the naturalization of

\footnotetext{
${ }^{9}$ See Perelmuter (2013).

${ }^{10}$ By 2013, a conflict between the provinces of Santiago del Estero and Tucumán, on the issue of pollutants generated from this production.
} 
differences that hide hierarchies' (De Sousa Santos 2006) for the rural world. By highlighting the appearance of a relationship among equals not only the primacy of the large corporations is naturalized, but also the universe of possible actors is reduced to those that demonstrate a business-oriented profile that adapts to the desires of the market.

In sum, the perspective that underlies the agribusiness logic is one that displaces the role of agriculture as a food or raw materials producer to one that is mandated by commodities. The international markets, of which the Chicago Board of Trade is the highest expression, are the ones that dictate the crops that must be produced to meet the world demand that in the vast majority of cases is completely disconnected from the needs of the local communities. More than this, the strength of these commands is such that it can even transform the eating habits of an entire country. Such is the case, that between the years 2000 and 2007, the consumption of soybean oil in Argentina grew by $224.5 \%$ becoming the most consumed oilseed product. Similarly soy lecithin replaced animal fat in most of the flour based food products (biscuits, breads, sweets, etc), a situation that has meant that the Argentinian population consumes daily genetically modified foods without any identification.

\section{The farmer or chacarerologic of production or 'process agriculture'11}

Finally, we want to refer to the last logic of food production: 'not peasants, nor agribusiness', updating anthropologists Archetti and Stölen's (1975) expression coined in the seventies to refer to chacareros or farmers as 'not peasants, nor capitalists'. We are referring here to the producer that in Argentina connects us to the colonization processes of the end of the nineteenth century and beginnings of the twentieth and that, with the democratic changes in the country, moved from land leaseholder of large landowners to become a small and medium landowner dedicated to food production. In our country, this mid-level agricultural producer shared the characteristic of serving both the local and the international market for export. This combination was possible because of the different institutions that regulated the sector and that disappeared in 1991 with the 'Deregulation Decree' of Menem-

\footnotetext{
"We thanks Engineer Alfredo Galli for the interesting and inspiring conversations on this issue.
} 
Cavallo. The characteristics of this producer included using family labour (like peasants), with a minimal use of agro-industrial inputs (especially agrochemicals ${ }^{12}$ ) and a staggered mechanization with strong technological innovation of the sector according to its needs, supported by the National Agricultural Technology Institute (INTA).

For the gringo ${ }^{13}$ colonist the land had a sense of a strong family patrimony that allowed the reproduction and education of the family and to pass it on to the next generation. Even if with the deregulation of 1991 and the approval of genetically modified seeds in 1996 (Menem-Solá) this farmer subject became a sojero ( the "small producer" of the soybean system) ${ }^{14}$, the original farmer (food producer) persists in other products. In a book from a few years ago, our research team titled the history of producers in Santa Fe's South as 'From colonists to sojeros' (Giarraca and Teubal 2005). Here, we explored this transformation process forced by the economic policies of the 90s that left many agricultural producers outside the market.

Is there today a chacarero food producer? Can we speak nowadays of this logic of food production as a contemporary one? This question is a central one, not only for the future of agriculture and food production in our country, but fundamentally because it is a political question. In fact, if the model of extractive activities becomes so consolidated with the advance of new technologies that the agribusiness logic colonizes all the agricultural spaces available with soybeans, genetically modified corn, feed lot in the cattle industry, etc., we will be in a situation very difficult to revert, and a very complex one not only in terms of 'food sovereignty' (the right to choose what we need) but also in the political power map of Argentina whether power is being held via land, capital or agricultural yield accumulation. For now, given the conditions of the so-called 'technological advances' we can confirm that there is a large portion of agricultural producers that are connected to food production and are not involved in the expansion of agribusiness. In our research, we refer to this sector

\footnotetext{
12 The great agrarian expansion of 1880 to 1930 happened without agrochemicals, which started to introduced towards the endo of this period. The increase in the use of agrochemicals in Argentina jumped from 10,000 liters per year in the 1970s to 270 millions of liters in 2010 of which 200 millions are of glyphosate.

13 In the Argentinian countryside colonists of immigrant background are colloquially known as gringo.

${ }^{14}$ We write "small producer" in inverted commas because we consider them to be contradictory, if a producer focuses on producing soybeans, then this producer cannot be consider a 'small' producer, except in relation to other soybean producers.
} 
as 'process agriculture' to distinguish from the previously discussed characteristics of the economic logic of agribusiness. We consider that this is still an important sector of agricultural production, especially in certain regions of the country. Looking at the path of evolution of the agrarian structure in the country (Fig. 1 below) we can understand that the potential of this category is still high.

\begin{tabular}{|c|c|c|c|c|c|}
\hline & $\begin{array}{c}\text { NAC } \\
1947\end{array}$ & $\begin{array}{c}\text { NAC } \\
1960\end{array}$ & $\begin{array}{c}\text { NAC } \\
1960\end{array}$ & $\begin{array}{c}\text { NAC } \\
1988\end{array}$ & $\begin{array}{c}\text { NAC } \\
2002\end{array}$ \\
\hline $\begin{array}{c}\text { Small } \\
\text { AH }\end{array}$ & 79.91 & 80.42 & 79.6 & 74.54 & 69.51 \\
\hline $\begin{array}{c}\text { Medium } \\
\text { AH }\end{array}$ & 14.27 & 13.81 & 14.31 & 18.20 & 20.73 \\
\hline $\begin{array}{c}\text { Large } \\
\text { AH }\end{array}$ & 5.82 & 5.77 & 6.09 & 7.26 & 9.76 \\
\hline Total & 100 & 100 & 100 & 100 & 100 \\
\hline
\end{tabular}

Figure 1 - Relative weight of Agricultural Holdings by classification according to

different census.

We cannot estimate what has happened in the years since 2002, because the 2008 National Agricultural Census (NAC) cannot be used (see Giarracca 2011). Yet, given the trends towards land and capital concentration imposed by the agribusiness model, it is expected that the first category of $\mathrm{AH}^{15}$ - small - will be reduced by many points. However, its relative importance, and that of the medium $\mathrm{AH}$ is still significant, especially outside of the Pampa region. We do not sustain, however, that the entire category is connected to the 'process agriculture' because there are many ways of incorporating land holdings into the logic of agribusiness without losing land ownership, but there is a part of this category that belongs to the logic of production that we are trying to characterize.

The AHs that still maintain the 'process agriculture' in regions where for climatic reasons (rain) genetically modified seeds can be used are very few, not to say nonexistent. We should analyze food production, but without the 2008 NAC it is a very difficult task to accomplish. Yet, in regions that produce other types of food - as or more important than grains and oilseed - such as horticulture, orchards, legumes, etc., can be easily found in areas outside of the Pampas region .

\footnotetext{
15 Translator's note: $\mathrm{AH}$ (Agricultural Holding) is Explotación Agropecuaria in Spanish.
} 
We consider that this sector, cornered by agribusiness (and by mining), contains the elements that can help in the configuration of a different agriculture for our country. These characteristics were clearly present in the decades of the twentieth century when agricultural production was consolidated, not only of grains but of other edible and non-edible products. This is to say that as a mode of production, it is embedded within the historical collective memory of the sector. It is not about imposing modes of production that are disconnected from the country's customs and traditions. Here lies the importance of showing some of the features of this third 'sector', seen as a continuum where some of these characteristics can be present to a lower or higher degree but that qualitatively distinguish it from the agribusiness.

These points, again, are gradual and we will show some examples of concrete processes in our country, to show how even with the variation in some of these there is still a difference when compared with the peasant and the agribusiness logics of production.

1. It is the head of the AH (individuals or small associations, like cooperatives) that makes the basic decisions of what, how and where to produce. This is based on the assumption that there is a particular type of knowledge the producer has connected to their experience that will lead them to make the best decisions for themselves and their communities (included the national community);

2. Crop rotation and, if possible, with cattle farming. Again, here is where the producer knows the advantages and disadvantages of specific productive combinations;

3. Diversification of production, both agrarian and of cattle farming. The diversification at a small scale is what ensures the micro-biological natural processes that avoid or reduce the need for agrochemicals;

4. All these characteristics by themselves lead to a higher use of labour. That is, they generate employment that can be family oriented or hired at a small scale (for harvests for example).

This model 'updated' to this century cannot be maintained without a strong political will (which is demanded by important sectors, both those affected and those that were not) but also by a new institutional structure that provides funding, technical 
advice (not propaganda of the latest corporation technology), infrastructure, and other ways of promoting exports, etc. But it is also necessary to pick up the pieces of cooperative markets; producers again, have a wealth of knowledge and experience in this area but it is surely out of date. It is not the same to export in 1970 than it is in 2015, yet there are many experiences that the federations of small producers and cooperatives know very well, from the now famous exporter cooperatives of grains to Canada (Abramovich and Amarilla 2011) to other Latin American forms. Without these weavings, the 'market' (meaning the large economic corporations) prevents the functioning of these systems. The advantages in comparison to agribusiness are clear: on the one hand, the conservation of land as a resource, and on the other hand to restore healthy conditions for the agrarian and rural population, while at the same time diversifying production, producing food and recovering food sovereignty.

\begin{tabular}{|c|c|c|c|}
\hline & \multicolumn{3}{|c|}{ Logics } \\
\hline & Peasant & Farmer - Chacarero & Agribusiness \\
\hline $\begin{array}{l}\text { Relationshi } \\
\text { p with land }\end{array}$ & $\begin{array}{l}\text { Territorial - Working } \\
\text { instrument - } \\
\text { Pachamama }\end{array}$ & Patrimonial & Commodity \\
\hline $\begin{array}{c}\text { Use of } \\
\text { techniques } \\
\text { Technology }\end{array}$ & $\begin{array}{l}\text { Use of external } \\
\text { techniques combined } \\
\text { with traditional } \\
\text { knowledge }\end{array}$ & $\begin{array}{l}\text { Gradual incorporation } \\
\text { of technology in } \\
\text { relation with the } \\
\text { family based } \\
\text { workforce available. } \\
\text { Mechanizzation with } \\
\text { a low level of } \\
\text { technology and } \\
\text { agrochemicals. }\end{array}$ & $\begin{array}{l}\text { Intensive use of } \\
\text { technology. High } \\
\text { level of agrochemicals }\end{array}$ \\
\hline $\begin{array}{c}\text { Produce } \\
\text { destination }\end{array}$ & $\begin{array}{l}\text { Local and regional } \\
\text { markets }\end{array}$ & $\begin{array}{l}\text { Internal and external } \\
\text { markets }\end{array}$ & External markets \\
\hline Labour use & Family workforce & $\begin{array}{l}\text { Combination of } \\
\text { familiar and salaried } \\
\text { workforce }\end{array}$ & $\begin{array}{l}\text { Salaried and } \\
\text { contractors }\end{array}$ \\
\hline
\end{tabular}

Figure 2 - Relative weight of Agricultural Holdings by classification according to different census. 
Three food production logics | 108

\section{Some reflections as concluding remarks}

It is clear that the advances of the agribusiness logic puts a mortgage on the territory of our country, makes the land a non-renewable resource and anticipates a dramatic end for Argentina, that had one of the most fertile fields of the planet. Yet, there are still other agricultural systems that with adequate encouragement can produce food, preserve the soil, generate employment and produce surplus for exportation. These can coexist adequately with peasant systems and with indigenous communities, without a need to engage in land-grabbing and they can also collaborate in local and regional markets.

The question that we have left is how to revert the tremendous expansion of the agribusiness logic, with its tendencies to non-rotation, monocropping and an export orientation, together with the social, environmental and particularly health consequences for the population that it brings about. It is a question that it is difficult to answer, when all the public policies tend to encourage this logic and discourage other systems.

At its core it is a cultural issue, a knowledge and power matrix that values what comes from a supposed 'modernization' and de-hierarchizes other forms or systems that do not require the inputs that the large corporations impose to the 'market'. This 'grave sin' - not to enter at a mass level in the international market of agroindustrial inputsmake these forms, what in modernizing language is termed 'backward'. If we add to this the Argentinian society modernizing 'vocation', particularly that of the big cities, we will understand why it is so difficult to include these elements in the discussions. We normally sustain that what the official discourse with their enlightened intellectual argues corresponds to the debates of the mid-twentieth century: developmentalism, the role of science within it, the modernizing motors of development, the sectors capable of introducing cutting edge technology, etc. All these elements were a part of the liberal hope of 'development' (hardly achieved by the periphery countries) and also of the critical theory that sought to 'develop the productive forces'.

Between the end of the second world war and the second decade of the twenty-first century many processes have wrecked the promises of modernity and shaken its three pillars: science, law and power (De Sousa Santos 2006). Modernity and all its semantic constellations: development, technological innovation, education as a tool for progress and the very concept of progress are in terminal crises if we consider the economic and social forces in USA and Europe in this last stage. It is no longer an 
economic or financial crisis, but, as we can easily see in those who resist within territorial struggles, it is a civilizational crisis. Paradoxically the news that now appear as hinges to new civilizational eras are emerging from the South. A Southern epistemology is created, where concepts such as food seovereignty, land rights, buen vivir, nature rights, etc are located, generating a performative thinking demonstrating that another world is, in fact, possible.

Even when in Latin America these other worlds are relatively significant, in Argentina, the impact of the extractive activities hides them and makes them invisible. It is because of that that from the critical thinking we are proposing to make space for the discussion and engagement of those involved in these small experiences. These are realities that spawn from the decisions of the peasant movement towards agroecology, to the unwavering struggles of the indigenous peoples for their ancestral territories, through the agricultural systems defined as process agriculture such as the agriculture and cattle farming system in the Famatina Valley (See Giarracca and Hadad 2009).

We know because we not only have research experience on these sectors, but also with the involvement in the design of transformative public policies ${ }^{16}$, that to modify the colossal expansion of the agribusiness more than the will of the actors involved is needed. There is a need for public policies that lead that change. But it is also true that most of the time, the public policies that are detrimental to the majority of people and to the territories end when those who are involved in 'street politics' manage to put a limit to the 'hegemonic order'. Let us remember that the first policies of neoliberalism - such as the privatization of all the social assets in Argentina - were reverted after the great 'Rebellion' of 2001-2002 when the financial capital took over the savings of the Argentinian people and people expressed their contempt to this form of governing. This goes to say that when a large sector of the population understands the large agribusiness corporations are appropriating common goods such as soil fertility for their own benefit, despite the large social suffering it creates, we may again be able to put limits to this hegemonic extractivist order.

\footnotetext{
16 Norma Giarracca participó en la Secretaría de Agricultura y Ganadería durante los años 19731974 cuando el Ing. Horacio Giberti emprendió con el Ministerio de Economía una indiscutida política a favor de la distri- bución de la riqueza agraria que terminaría con la muer- te del presidente Perón y la renuncia del ministro de Economía, José Gelbard.
} 
Three food production logics | 110

\section{References}

Abramovich, F. y Amarilla, C. 2011 "Situación actual y perspectivas del comercio de granos en la Argentina", ponencia presentada en las IV Jornadas de Economía Crítica, 25 a 27 de agosto, Córdoba, Argentina.

Aparicio, S. 2005 "Trabajos y trabajadores en el sector agropecuario de la Argentina" en Giarracca, N. y Teubal, M. (coords.) El campo argentino en la encrucijada (Buenos Aires: Alianza).

Archetti, E. y Stölen, K. 1975 Explotación familiar y acumulación de capital en el campo argentino (Buenos Aires: SigloXXI).

Bartra, A. 1979 La explotación del trabajo campesino por el capital (México DF: Macehual).

De Sousa Santos, B. 2006 Renovar la teoría critica y reinventar la emancipación social. Encuentros en Buenos Aires (Buenos Aires: CLACSO / Facultad de Ciencias Sociales, UBA).

Giarracca, N. 2011 "El fracaso del Censo Nacional Agropecuario" en Giarracca, N. y Teubal, M. (comps.) Del paro agrario a las elecciones de 2009 (Buenos Aires: Antropofagia).

Giarracca, N. y Hadad, G. 2009 "Disputas manifiestas y latentes en La Rioja minera. Política de vida y agua en el centro de la escena" en Svampa, M. y Antonelli, M. (eds.) Minería trasnacional, narrativas del desarrollo y resistencias sociales (Buenos Aires: Biblos).

Giarracca, N. y Teubal, M. (coord.) 2005 El campo argentino en la encrucijada: estrategias y resistencias sociales, ecos en la ciudad (Buenos Aires: Alianza).

Giarracca, N. y Teubal, M. 2008 "Del desarrollo agroindustrial a la expansión del 'agronegocio': el caso argentino" en Mançano Fernandes, B. (org.) Campesinato e agronegócio na América Latina: a questão agrária atual (San Pablo: CLACSO).

Grupo de Estudios Rurales (GER) 2004 "Desalojos y arrinconamientos de campesinos y comunidades indígenas en la Argentina" en Realidad Económica (Buenos Aires) No 203, abril-mayo. 
Grupo de Estudios sobre Ecología Política, Comunidades y Derechos (GEPCyD) 2010 "La violencia rural en la Argentina de los agronegocios: crónicas invisibles del despojo", ponencia presentada en las VI Jornadas de Antropología Social (Buenos Aires: 3-6 de agosto.

Mariotti, D. 2011 "Estrategias sociales y acciones colectivas de la Unión de Cañeros Independientes de Tucumán. Una historia sobre la herejía, la infamia y lo profano", tesis de doctorado, Facultad de Ciencias Sociales, Universidad de Buenos Aires, 4 de noviembre.

Teubal, M. y Rodríguez, J. 2002 Agro y alimentos en la globalización. Una perspectiva crítica (Buenos Aires: La Colmena).

Vía Campesina 2010 Revolución agroecológica: El Movimiento de Campesino a Campesino de la ANAP en Cuba (s/d: Vía Campesina) 